\title{
A NEW RETINIA ATTACKING AUSTRIAN PINE.
}

by A, Cosens, JAMieson ave. Coldegiate institule, toronto.

Retinia Austriana, n. sp.--The Austrian Pine (Pinus laricio Austriaca) in the vicinity of Toronto is badly infested by the larve of a moth which is apparently an undescribed species of the genus Retinia. It resembles in certain particulars the form Retinia Comstockiana. This species was described in the Canadian ENTomologist of Aug., i 879, by Prof. C. H. Fernald, State College, Orono, Me. The specimens, however, were obtained at Ithaca. N. Y., where they were found boring in the small branches of Pinus rigida.

The Toronto species burrows in the cortical layer of the Austrian Pine. The tunnels formed pierce the resin ducts, the gum exudes and hardens into masses on the bark of the trees. The point of attack appears to be usually beneath the origin of a limb. The larve work on a more or Jess horizontal plane, and in consequence of this the trees have been, in some cases, almost girdled.

This form also resembles $R$. Comstockinna in its life-history. The larva when mature burrows into the lump of resin that has hardened over the eutrance to its tumnel, and there pupates. The thin covering of gum left over the burrow is broken through by the imago when it emerges.

The larva prepares its burrow in the lump of resin in a very characteristic manner. Two larve were placed on a mass of the gum, and in a remarkably short time they had sheltered themselves in it. Their mode of operation was as follows: Selecting an accidental crevice in the resin, they crawled into it, and immediately began to weave threads of silk across the opening. The burrow was then enlarged by biring off pieces of the gum. The little masses broken off were disposed of by being forced against the covering of silk threads until they adbered to it. This very soon so effectually closed the burrow as to make it a matter of some difficulty to find its location. This closing of the burrow, when done under natural conditions, may be a means of preventing further exudation of resin. In all the cases examined the tunnel appeared to be quite open for some distance behind the pupa.

In High Park, Toronto, nearly all the Austrialu Pines are infested. In all cases the trees are being materially injured, and in some cases have been killed. Trees of the same species in other Toronto localities have been found to be infested.

The ravages of this moth are checked by parasitic agency to a certain extent, as an Ichneumon Fly emerged from a mass of resin collected by the writer.

November, 1906 
Retinia Austriana, n. sp.-Larva: Length, 15-16 mm. Whitish, with a slightly silvery lustre. The last segment marked with dark spots on the dorsal surface. A few fine hairs on each segment of the body. Body wall very transparent.

Pupa: Length, $\mathrm{I}_{3}-\mathrm{I} 5 \mathrm{~mm}$. Light brown in colour.

Imago: \&.-Expanse, $20-22 \mathrm{~mm}$.

Head: Erown, flecked with a few white silvery scales. Antennæ brown, each joint marked above with the silvery.white scales. Basal joints silvery.white above. Palpi dark brown, mottled with a few white scales. Eyes a lighter brown than the head. The scales project in the form of a ruff at the origin of the head. This is especially well marked on the dorsal surface.

Thorax: Above dark brown, shading into a lighter silvery-brown anteriorly. Beneath a mottled white and brown, with a silvery lustre, the white slightly predominating.

Aodonen: Above light brown, with a silvery lustre, each segment ending with a narrow band of silvery white scales. Beneath the white and brownish scales are about equally mixed. Towards the posterior end of the segments the white scales are slightly predominant. Anal tuft light brown.

Legs: The femora and tibiæ of the two anterior pairs dark brown, motiled with silvery-white scales. Tarsi dark brown, each segment ending in a ring of silvery-white. The femora and tibiæ of the posterior pair are silvery-white, flecked with a few brownish scales. Tarsi lighter. in colour than in the two anterior pairs.

Wings: Fore wings above light silvery brown, mottled with silvery white. A wide irregular band of dark brown, interspersed with a few white scales, runs along the entire costal edge, while a narrow edging of dark browı bounds the outer margin. Two wavy bands of whitish silvery scales pass across each wing at nearly right angles to the costa, and divide the wing into three nearly equal parts. These bands are margined with dark brown. The distal third of the wing shades off into whitish, where it is bounded by the dark band on the outer margin of the wing. Beneath these wings are a light silvery-brown, shading into a little darker at the costal and outer margins. The markings of the upper surface do not show through. The fringe of these wings is a light brown, with a silvery lustre. The colour is slightly lighter at the iips.

Hind Wings: Above white, with a decided silvery lustre. An irregular band of light brown along the costal margin, while a narrow line 
of silvery light brown bounds the outer margin. Beneath as above, but the brown edgings are not so pronounced. The fringe is silvery-white, shading into light brown along the line of attachment opposite the brown line on the outer margin of the wing. The fringe on the distal margin is light brown.

\section{SOME CARPENTER-BEES FROM AFRICA. \\ BY T. D. A. COCKERFLL, BOUlder, COLO.}

I am indebted to Dr. F. Creighton Wellman for specimens of two little-known species of Xylocopidæ, collected by himself in Angola. Although they are not new species, they suggest a few observations.

Mesotrichia mixta (Radoszkowski, I881).

Two females, Chyaka, Angola, July, 1906, on mountain side, 6,000 feet. Dr. Wellman says: "Seen at several flowers. These taken at a species of Millettia, of which they are very fond."

The genus Mesotrichia seems sufficiently distinct from Xylocopa to be maintained, but I think Koptorthosoma, Gribodo, is only a subgenus of it. Ashmead separates Mesotrichia from Koptorthosoma by the characters, "second cubital cell, along the cubitus, much longer than the first; mandibles tridentate," as well as certain peculiarities of the males. $M$. mixta, however, has the venation of Mesotrichia, with the bidentate mandibles of Koptorthosoma. Vachal suggests that $M$. mixta may be a variety of Mesotrichia favorufa (Apis flavorufa, DeGeer, I778), but the true farvoruf $a$ appears to be confined to the eastern side of the continent, and I think mixta is certainly a valid species.

Xylocopa tarsata, Smith, 1854, var. Wellmani, v. nov., Bailundo, Angola, Feb.-March, I 906, 4.700 feet. "Taken at various Malvaceæ, principally Gossypium spp." Both sexes sent. The insect agrees with Smith's brief description, except that it is a little longer, and the hind tibiæe are covered with red hair on the outside (Smith speaks of it as being confined to the apex). The male, not hitherto described, has the clypeus (except the lower margin), a broad stipraclypeal mark, and lateral facemarks filling in the space between eyes and clypeus, and ending abruptly at level of antennæ, ail bright chrome-yellow. The labrum is black, with a central tubercle. The hind femora are much swollen, and have a large basal tooth, directed downwards, and apicad beneath; the hind trochanters have a large tooth directed backwards over the coxa. The insect is nearly I $8 \mathrm{~mm}$. long. Vachal has suggested that $X$. albifrons, Lep., is the male of tarsata, but it is quite distinct from the Angola maie. Since the Angola insect is not quite the same as true tarsata (from the Cape of Good Hope) in the female, and the male is like nothing yet seen in the original locality of tarsata, I propose to call Dr. Wellman's insect $X$. tarsata Wellmani.

November, 1906 